\title{
Two-Phase Numerical Modelling of a Wet Exhaust System in a Catamaran Motor Yacht Diesel Engine
}

\author{
Alihan Cambaz ${ }^{* 1}$, Yasin Furkan Gorgulu², Halit Arat $^{3}$ \\ ${ }^{* 1}$ SU Ar-Ge Dizayn ve Mühendislik A.Ş, 77000, Yalova-Turkey, (ORCID: 0000-0001-6632-978X), cambazalihan7@gmail.com \\ ${ }^{2}$ Mechatronics Engineering Department, Istanbul Health \& Technology University Engineering and Natural Sciences Faculty, 34025, Istanbul-Turkey, (ORCID: 0000- \\ 0002-1828-2849), furkan.gorgulu@istun.edu.tr \\ ${ }^{3}$ Mechanical Engineering Department, Kutahya Dumlupinar University Engineering Faculty, 43270, Kutahya-Turkey, (ORCID: 0000-0002-6634-2535), \\ halit.arat@dpu.edu.tr
}

(First received 8 October 2021 and in final form 10 December 2021)

(DOI: 10.31590/ejosat.1007351)

ATIF/REFERENCE: Cambaz, A., Gorgulu, Y. F. \& Arat, H. (2021). Two-Phase Numerical Modelling of a Wet Exhaust System in a Catamaran Motor Yacht Diesel Engine. European Journal of Science and Technology, (31), 165-170.

\begin{abstract}
In this study, multiphase temperature distributions and volume fractions through a wet exhaust system were investigated as 3D by using a comprehensive numerical model in a yacht diesel engine. For this purpose, the Volume of Fluid multiphase model was selected as the numerical model. Fuel exhausts are generally located underwater to ensure a modern yacht appearance and minimize exhaust noise. A scoop is positioned above the catamaran yacht exhaust to control water pressure, exhaust gases, and cooling water flow distribution. Besides, two types of fluids have been used, one of which is the hot exhaust gas the other is the cooling water used in the nozzle. The design has been created using Ansys SpaceClaim, and the cooling water is sprayed from the $60^{\circ}$ tip of the nozzle. Moreover, the mesh used in the simulation has 1,405,113 elements, 523,125 nodes, and the average mesh skewness is 0.46, the average orthogonal quality of the mesh is 0.64 . The Realizable k- $\varepsilon$ turbulence model has been used in the simulations. According to the results, the flow fully develops after 1.5 seconds, and the water nozzle sprays the water along the tube cools the exhaust gases. Also, the stagnation points occurring at the elbow fitting of the tube are striking when the velocity contours and velocity vectors are examined.
\end{abstract}

Keywords: Wet exhaust system, Marine diesel engine, CFD, Thermal performance, Two-phase flow.

\section{Bir Katamaran Motoryat Dizel Motorunda Bir Islak Egzoz Sisteminin İki Fazlı Sayısal Modellenmesi}

\section{Öz}

Bu çalışmada, bir yat dizel motorunda kapsamlı sayısal model kullanılarak ıslak egzoz sisteminden çok fazlı sıcaklık dağılımları ve hacim fraksiyonları 3 boyutlu olarak incelenmiştir. Bu amaçla sayısal model olarak Volume of Fluid çok fazlı modeli seçilmiştir. Yakıt egzozları, modern bir yat görünümü sağlamak ve egzoz gürültüsünü en aza indirmek için genellikle su altında bulunmaktadır. Su basıncını, egzoz gazlarını ve soğutma suyu akış dağıtımını yönetmek için katamaran yat egzozunun üzerine bir muhafaza yerleştirilmiştir. Bununla birlikte, nozulda kullanılan sıcak egzoz gazı ve soğutma suyu olmak üzere iki tip akışkan kullanılmıştır. Tasarım Ansys SpaceClaim kullanılarak oluşturulmuştur ve soğutma suyu nozulun $60^{\circ}$ ucundan püskürtülecek şekilde ele alınmıştır. Dahası simülasyonda kullanılan yapısal ağ 1.405 .113 elemana ve 523.125 düğüme sahiptir ve ortalama yapısal ağın çarpıklığı 0,46 , meshin ortalama ortogonal kalitesi 0,64 'tür. Simülasyonlarda Realizable k- $\varepsilon$ türbülans modeli kullanılmıştır. Sonuçlar incelendiğginde, 1,5 saniye sonra akış tam olarak gelişmekte ve su nozulu, suyu boru boyunca püskürtmekte ve egzoz gazlarını soğutmaktadır. Ayrıca hız konturları ve hız vektörleri incelendiğinde borunun dirsek bağlantı noktasında meydana gelen durma noktaları dikkat çekicidir.

Anahtar Kelimeler: Islak egzoz sistemi, Deniz dizel motoru, CFD, Termal performans, İki fazlı akış.

\footnotetext{
* Corresponding Author: cambazalihan7@gmail.com
} 


\section{Introduction}

In recent days, air pollution caused by diesel-powered automobiles and ships has been one of the most critical damages of global warming (Aydın \& İlkılıç, 2017; X. C. Wang et al., 2019). The ships' diesel engine emissions have significantly contributed to environmental issues such as acidification, eutrophication, and potential health dangers (Magnusson et al., 2016; Ryu et al., 2020). In order to avoid these harmful effects, global organizations like International Maritime Organisation (IMO) enacted some regulations related to reducing ozonedepleting substances and greenhouse gas (GHGs) emissions (Blasco et al., 2014). Moreover, several countries are working on energy-saving and emission-reduction technologies for ships. One of them is the selective catalytic reduction (SCR) system, which has a remarkable denitrification effect. (M. Wang et al., 2019). NOx produced during the combustion process is decreased downstream of the engine using SCR technology, which is a post-treatment technique (Hao et al., 2022; Lee et al., 2021). The exhaust gas temperature at the SCR system's inlet is a crucial parameter in SCR operating (Foteinos et al., 2020).

The exhaust gases pass through the SCR discharge into the atmosphere air or seawater with the exhaust systems. These systems containing different techniques like backpressure control, noise attenuation, anti-vibration, exhaust cooling are used to meet the required standards (Engineering Techniques MarQuip B.V. Exclusive Yacht Exhausts, n.d.). In general, a few of these techniques are collocated, as in wet exhaust systems, which reduce noise, heat, and scent. The wet exhaust injects cooling water into the piping, and so the exhaust pushes the water out of the piping (Dry and Wet Exhaust. - AB Marine Service, n.d.; Exhaust System Basics | West Marine, n.d.). Other advantages of underwater discharge are that it reduces the risk of hot spot detection on naval ships and improves the aesthetics of luxury ships by eliminating bulky and unattractive vertical exhaust funnels that cross the deck. However, the exhaust gases go through a flow resistance due to the pressure applied by the water at the outlet of underwater exhaust systems (H. Sapra et al., 2017).

There are rare studies on the backpressure of marine exhaust systems, although these work items with some limitations are

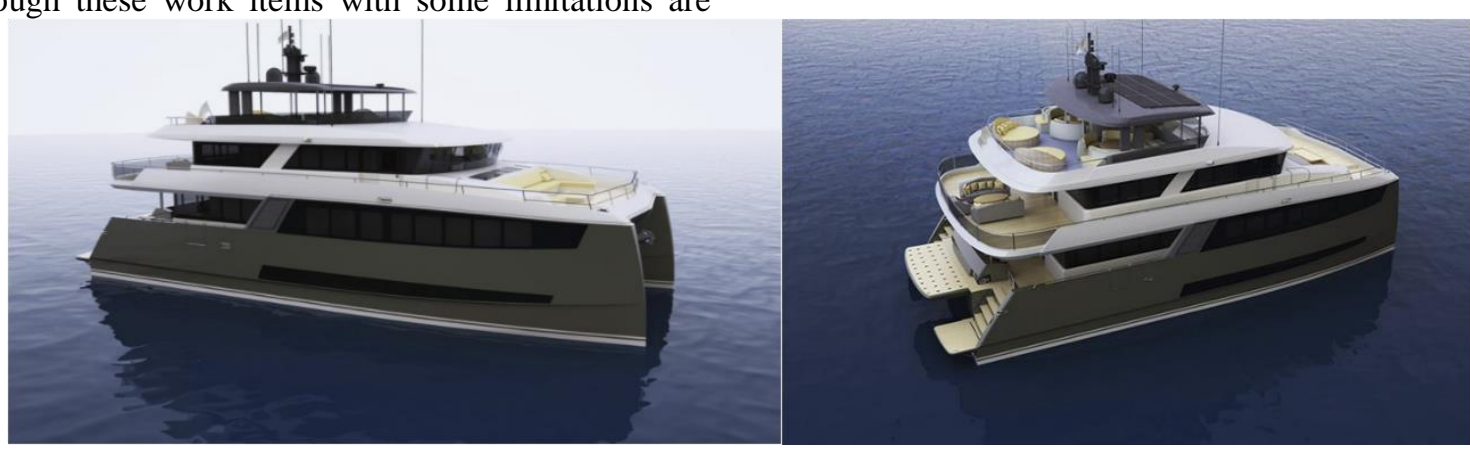

Figure 1. A catamaran motor yacht (Zeng, 2021).

The catamaran yacht has a MAN marine engine with a $4,880-\mathrm{kW}$ engine output. Therefore, the engine exhaust system has been designed according to the engine details. In the literature and also in applications, various exhaust designs are being used. A water-cooled wet exhaust system has been more important for marines. Sapra et al.(H. D. Sapra et al., 2020) have experimentally tested the marine diesel engine performance to reveal single and multiple backpressure waves of different amplitudes and wave durations. Fernoaga et al. (Fernoaga et al., 2020) have analyzed experimental data from instrumentalized diesel engine test-beds as training data for artificial neural network analysis and regressors to examine the impact of exhaust backpressure characteristics. Besides, Zhu et al. (Zhu et al., 2020) have simulated the vaporizer/mixer of high-pressure $\mathrm{SCR}$ in a marine diesel engine to investigate the parameters like chemical reaction, pressure loss, flow velocity, and species concentration uniformity as a numerical study from the literature.

According to the previous studies in the literature, the exhaust systems of marine diesel engines aim to reduce harmful emissions and find pressure loss. In this study, the multiphase temperature distributions and volume fractions through a wet exhaust system were investigated as $3 \mathrm{D}$ by using a comprehensive numerical model in a yacht diesel engine.

\section{Material and Method}

\subsection{Catamaran Yacht Engine Underwater Exhaust System}

Fuel exhausts are generally located underwater to ensure a modern yacht appearance and minimize exhaust noise. A scoop is positioned above the catamaran yacht exhaust to control water pressure, exhaust gases, and cooling water flow distribution. Modeling and simulating tools are being used to analyze the impact of various flow parameters on designs. Ansys Fluent has been used in the study for simulating the exhaust gases and the cooling water. The method of utilizing Computational Fluid Dynamics (CFD) to forecast the performance is aimed in the study. Therefore, it provides significant benefits in terms of increased understanding, decreased uncertainty, and the elimination of the need for lengthy physical testing (Case Study: CFD Simulation of an Underwater Yacht Exhaust - Femto Engineering - Femto Engineering, n.d.). A catamaran motor yacht can be seen in Figure 1.

designed for the catamaran yacht. The design has been created using Ansys SpaceClaim. The design is shown in Figure 2 and the exhaust gas inlet, water inlet, and outlet. The cooling water is sprayed from the $60^{\circ}$ tip of the nozzle. 


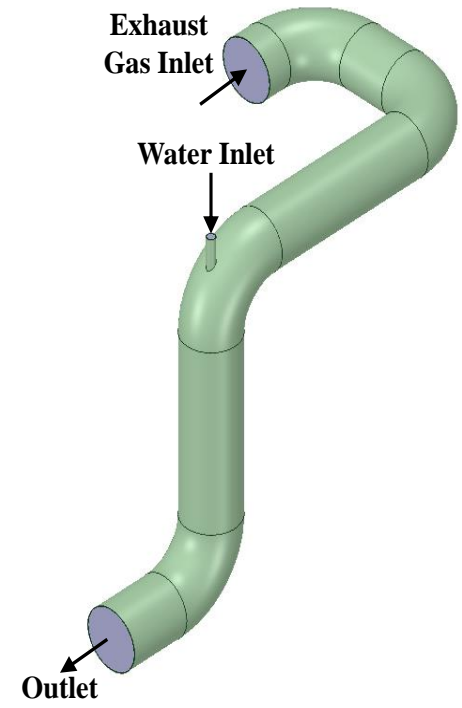

Figure 2. The exhaust design for the catamaran yacht.

\subsection{Computational Fluid Mechanics (CFD)}

Ansys Fluent has been used as the flow simulation program in the study. Two types of fluids have been used: the hot exhaust gas the other is the cooling water used in the nozzle. There are several methods for two-phase flow simulations, such as Level Set, Front Tracking Scheme, and Volume of Fluid methods (M \& Tomar, 2021; Prosperetti \& Tryggvason, 2007; Tryggvason et al., 2003). In order to model a two-phase flow, the Volume of Fluid method designed to track the location and motion of free surface between two or more immiscible has been used (Arat et al., 2021; Guerrero et al., 2017). The volume of the two phases is fully conserved utilizing the volume of fluid techniques with geometric advection. The Realizable k-epsilon $(\mathrm{k}-\varepsilon)$ turbulence model has been used in the simulations. The realizable kturbulence model benefits from improving predictions for the effuse rate of planar and round jets. Realizable k- $\varepsilon$ shows a more remarkable performance to capture the mean flow of complicated structures in nearly every comparison. It also performs other flow types better, such as boundary layers under high-pressure gradients, recirculation rotation, and separation (Bardina et al., 1997; K-Epsilon Models, 2011; Nesbitt et al., 1992). Ansys placed control mechanisms such as orthogonal quality and skewness ratios for understanding the quality of the mesh. It is recommended the average skewness values be between the range of $0.25-0.50$ is an excellent quality mesh. For the orthogonal quality, that range reaches out to $0.20-0.69$ and is considered good quality (Ansys Inc., 2011; GORGULU et al., 2021). In this case, the average mesh skewness is 0.46 , the average orthogonal quality of the mesh is 0.64 . The mesh used in the simulation has $1,405,113$ elements and 523,125 nodes. The mesh structure of the catamaran yacht exhaust and the close-up view of the nozzle are given in Figure 3.

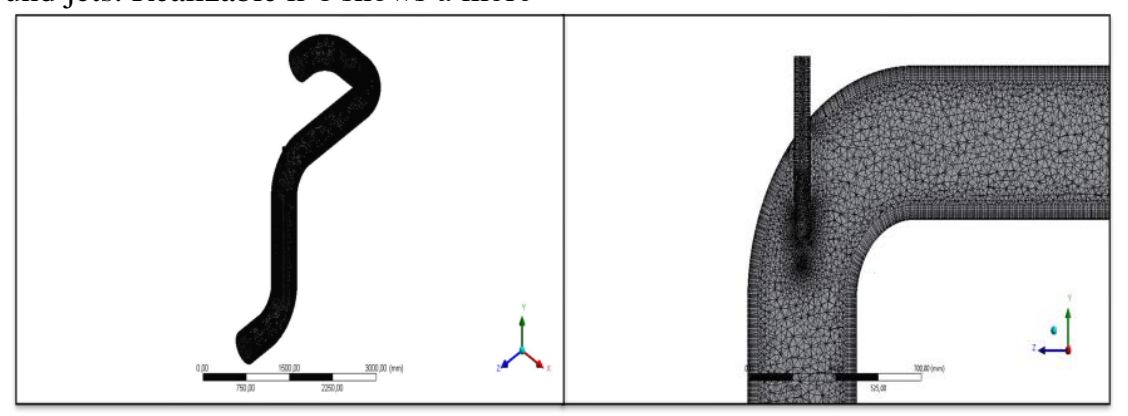

Figure 3. The mesh structure of the catamaran yacht exhaust and close-up view of the nozzle.

The transient and time-dependent solution has been used throughout the simulation. The simulation has a total of 2.5second duration. Two fluid inlets have been defined in the simulation. One of the inlets is a hot exhaust gas inlet, and the other is the cold-water inlet. Gas enters the tube with a velocity of $40 \mathrm{~m} / \mathrm{s}$ and a temperature value of $585 \mathrm{~K}$, while the nozzle sprays the water with a four $\mathrm{m} / \mathrm{s}$ velocity at $305 \mathrm{~K}$.

\section{Results and Discussion}

The multiphase temperature distributions and volume fractions through a wet exhaust system were investigated as 3D using a comprehensive numerical model in a yacht diesel engine. Temperature contours have been taken with a time interval of 0.5 seconds, and they are demonstrated in Figure 4. 


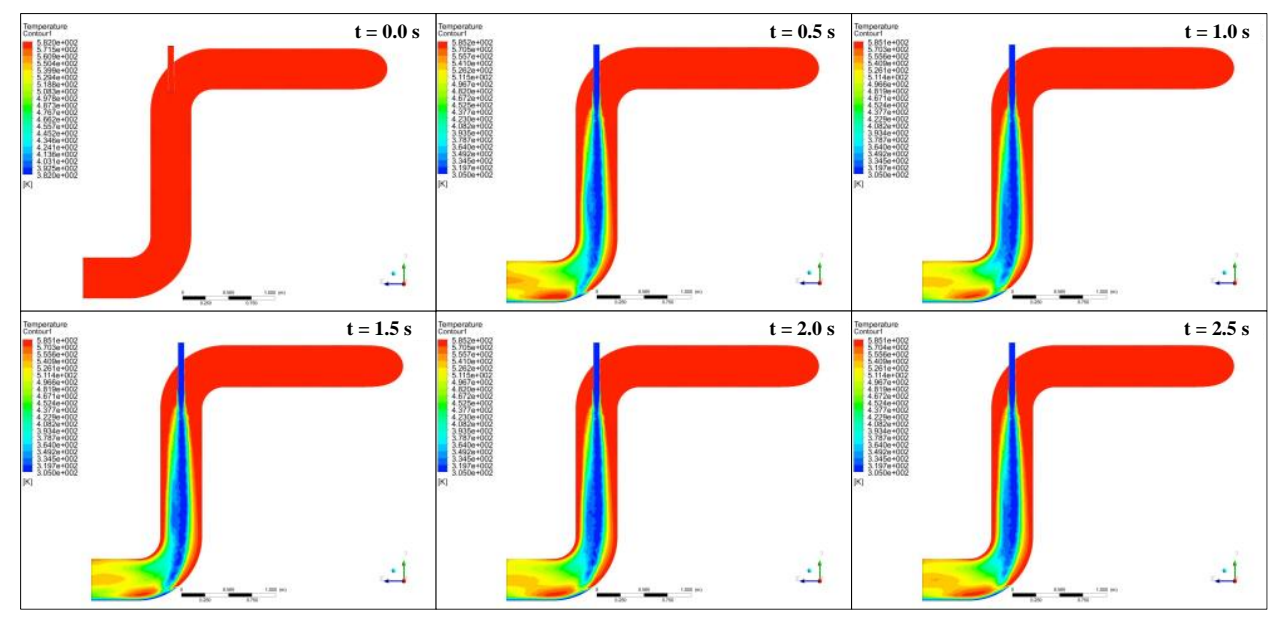

Figure 4. The temperature contours of the catamaran yacht exhaust.

According to Figure 4, it can be stated that as the flow fully develops, the water nozzle sprays the water along the tube cools the exhaust gases. At the lowest level of the tubes, there is a water stagnation at the 90 degrees elbow fitting due to the friction. Another contour has been taken at the exhaust outlet to understand the temperature change that occurred just before it was released into the atmosphere. It can be seen in Figure 5.
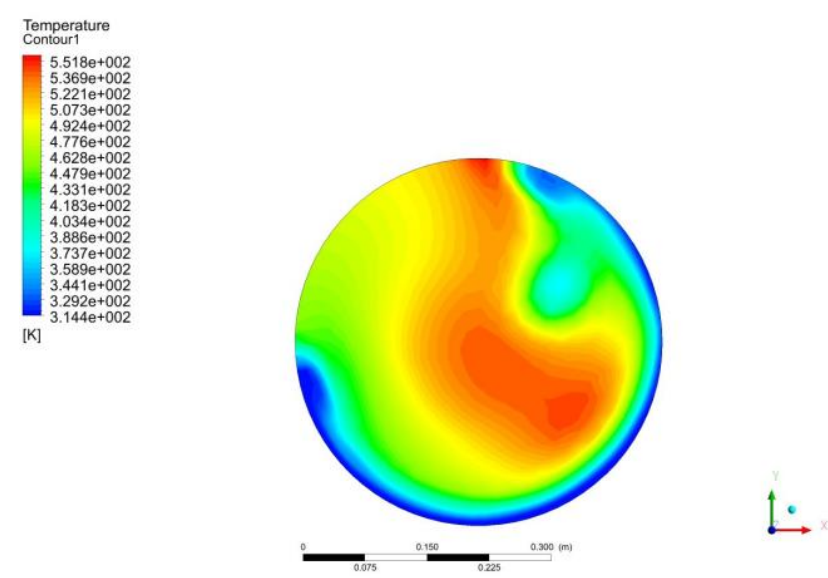

Figure 5. The temperature contours at the exhaust outlet.

It is clear that the walls are primarily cooled in Figure 5. As proceeded to the center, the temperature is increased. A heterogeneous contour draws attention. This indicates that the design needs to be further optimized in terms of temperature distribution. The temperature values are changed between $314.4 \mathrm{~K}$ and $551.8 \mathrm{~K}$. Other than the temperature distributions, velocity and pressure contours have been created. The velocity contours and vectors for different locations are given in Figure 6. 


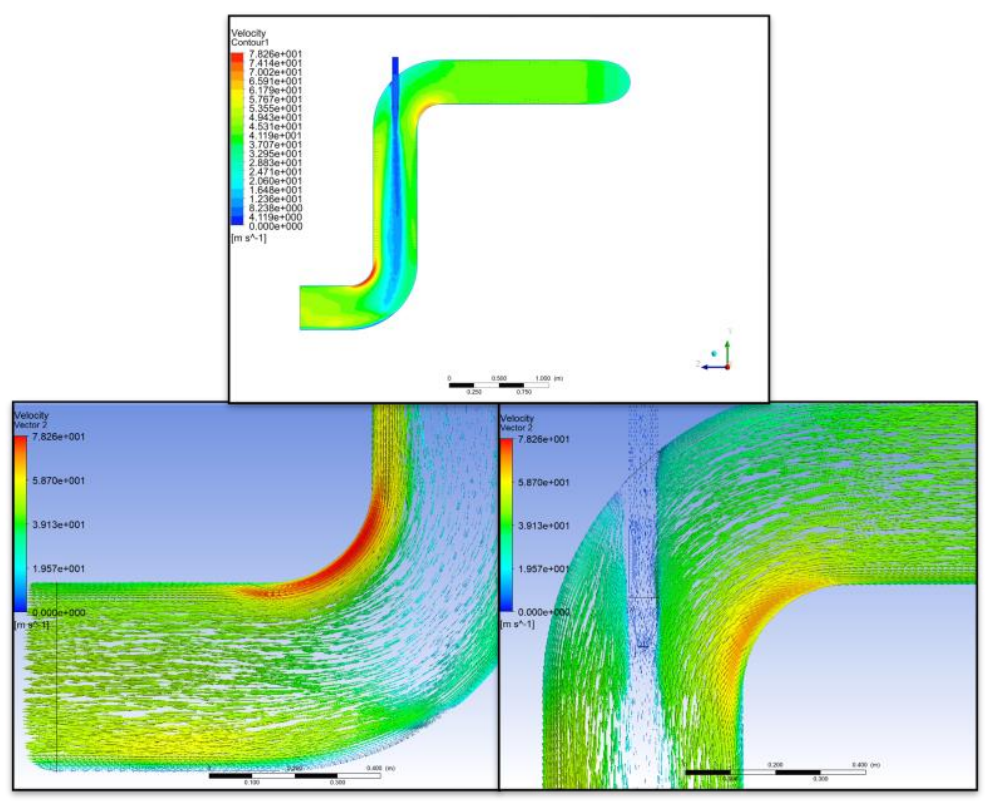

Figure 6. The velocity contours and vector view of the catamaran yacht exhaust.

In Figure 6., the first picture shows the velocity contours, and the others are the velocity vector views at elbow fittings. When the velocity contours and velocity vectors are examined, the stagnation points occurring at the elbow fitting of the tube are striking (Ozkara et al., 2019). The flow occurring in the elbows in the exhaust design can be seen in the figure, allowing designers to design according to the flow events here. Also, there might be tips to eliminate these issues in future work. The numerical pressure contours are given in Figure 7.

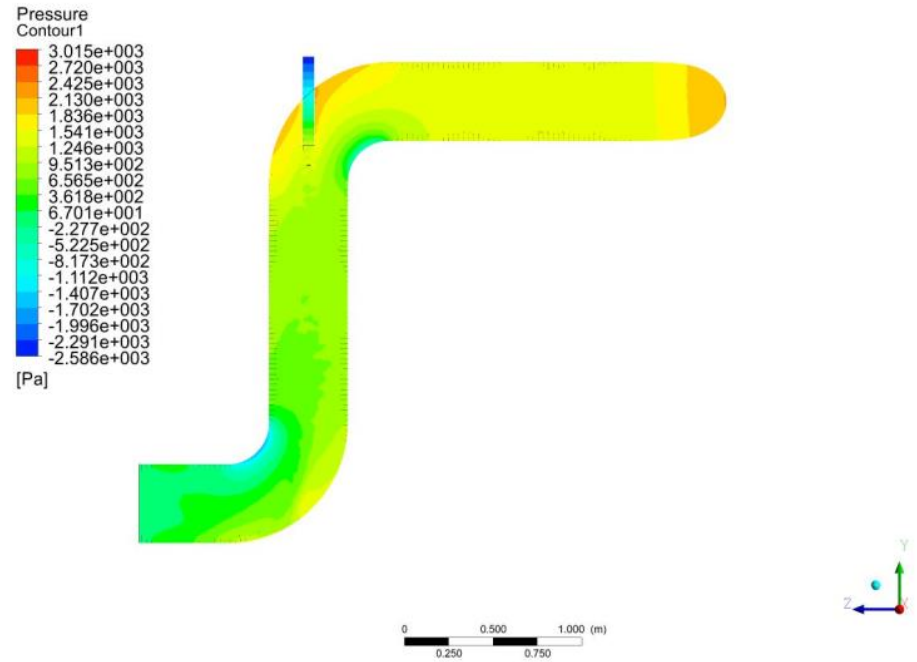

Figure 7. The pressure contours of the catamaran yacht exhaust.

\section{Conclusions and Recommendations}

In this study, the multiphase temperature distributions and volume fractions through a wet exhaust system were investigated as 3D using a comprehensive numerical model in a yacht diesel engine. For this purpose, the Volume of Fluid multiphase model was selected as the numerical model. Also, the Realizable $\mathrm{k}-\varepsilon$ turbulence model has been used in the simulations performed as transient and time-dependent with a total of 2.5-second duration.

According to the results, the flow fully develops after 1.5 seconds, and the water nozzle sprays the water along the tube cools the exhaust gases. Also, the stagnation points occurring at the elbow fitting of the tube are striking when the velocity contours and velocity vectors are examined. Moreover, the pressure increase is observed where exhaust gas and cooling water meet with shocks at some points. On the other hand, the flow occurring in the elbows in the exhaust design allows the designers to design according to the flow events, and also, there might be tips to eliminate these issues in future work. Furthermore, the numerical analysis of the underwater wet exhaust system will continue as a parametric study with different designs in detail.

\section{Acknowledge}

The authors would like to express their appreciation to "SU Ar-Ge Dizayn ve Mühendislik A.Ş.” for their assistance throughout the study. 
The authors declare that they have no conflict of interest. Also, the research presented in the manuscript did not receive any external funding.

\section{References}

Ansys Inc. (2011). Introduction to Ansys Meshing (pp. L5-16). Ansys Inc.

Arat, H., Arslan, O., Ercetin, U., \& Akbulut, A. (2021). A comprehensive numerical investigation of unsteady-state two-phase flow in gravity assisted heat pipe enclosure. Thermal Science and Engineering Progress, 25. https://doi.org/10.1016/j.tsep.2021.100993

Aydın, H., \& İlkılıç, C. (2017). Air pollution, pollutant emissions and harmfull effects. Journal of Engineering and Technology, 1(1), 8-15.

Bardina, J. E., Huang, P. G., \& Coakley, T. J. (1997). Turbulence modeling validation. 28th Fluid Dynamics Conference, April. https://doi.org/10.2514/6.1997-2121

Blasco, J., Durán-Grados, V., Hampel, M., \& Moreno-Gutiérrez, J. (2014). Towards an integrated environmental risk assessment of emissions from ships' propulsion systems. Environment International, 66. https://doi.org/10.1016/j.envint.2014.01.014

Case study: CFD Simulation of an underwater yacht exhaust Femto Engineering - Femto Engineering. (n.d.). Retrieved September 7, 2021, from https://www.femto.eu/stories/cfdsimulation-yacht-exhaust/

Dry and wet exhaust. - AB Marine service. (n.d.).

Engineering techniques - MarQuip B.V. Exclusive Yacht exhausts. (n.d.).

Exhaust System Basics | West Marine. (n.d.).

Fernoaga, V., Sandu, V., \& Balan, T. (2020). Artificial intelligence for the prediction of exhaust back pressure effect on the performance of diesel engines. Applied Sciences (Switzerland), 10(20). https://doi.org/10.3390/app10207370

Foteinos, M. I., Christofilis, G. I., \& Kyrtatos, N. P. (2020). Response of a direct-drive large marine two-stroke engine coupled to a selective catalytic reduction exhaust aftertreatment system when operating in waves. Proceedings of the Institution of Mechanical Engineers Part M: Journal of Engineering for the Maritime Environment, 234(3). https://doi.org/10.1177/1475090219899543

GORGULU, Y. F., OZGUR, M. A., \& KOSE, R. (2021). CFD analysis of a NACA 0009 aerofoil at a low reynolds number. Journal of Polytechnic, 0900, 0-1. https://doi.org/10.2339/politeknik.877391

Guerrero, E., Muñoz, F., \& Ratkovich, N. (2017). Comparison between eulerian and vof models for two-phase flow assessment in vertical pipes. CTyF - Ciencia, Tecnologia y Futuro, 7(1), 73-84. https://doi.org/10.29047/01225383.66

Hao, C., Zhang, C., Zhang, J., Wu, J., Yue, Y., \& Qian, G. (2022). An efficient strategy to screen an effective catalyst for NOx-SCR by deducing surface species using DRIFTS. Journal of Colloid and Interface Science, 606, 677-687. https://doi.org/10.1016/J.JCIS.2021.08.070

K-epsilon models. (2011). https://www.cfd-online.com/Wiki/Kepsilon_models

Lee, Y., Lee, S., Lee, S., Choi, H., \& Min, K. (2021). Characteristics of NOx emission of light-duty diesel vehicle with LNT and SCR system by season and RDE phase. Science of the Total Environment, 782, 146750. https://doi.org/10.1016/j.scitotenv.2021.146750

M, A., \& Tomar, G. (2021). Interface reconstruction and advection schemes for volume of fluid method in axisymmetric coordinates. Journal of Computational Physics, 110663. https://doi.org/10.1016/j.jcp.2021.110663

Magnusson, M., Fridell, E., \& Härelind, H. (2016). Improved low-temperature activity for marine selective catalytic reduction systems. Proceedings of the Institution of Mechanical Engineers Part M: Journal of Engineering for the Maritime Environment, 230(1). https://doi.org/10.1177/1475090214536546

Nesbitt, T. S., Arevalo, J. A., Tanji, J. L., Morgan, W. A., \& Aved, B. (1992). Will family physicians really return to obstetrics if malpractice insurance premiums decline? The Journal of the American Board of Family Practice / American Board of Family Practice, 5(4), 413-418. https://doi.org/10.3122/jabfm.5.4.413

Ozkara, M., Ercetin, U., Doner, N., \& Sen, F. (2019). Numerical Investigations of Stall Development in a Transonic Axial Compressor Stage. BioNanoScience, 9(2), 461-473. https://doi.org/10.1007/s12668-019-0599-7

Prosperetti, A., \& Tryggvason, G. (2007). Computational Methods for Multiphase Flow (Vol. 148). Cambridge University Press.

Ryu, Y., Kim, T., Kim, J., \& Nam, J. (2020). Marine Science and Engineering Investigation on the Emission Characteristics with a Wet-Type Exhaust Gas Cleaning System for Marine Diesel Engine Application. Journal of Marine Science and Engineering, $\quad 8(11)$, https://doi.org/10.3390/jmse8110850

Sapra, H. D., Singh, J., Dijkstra, C., de Vos, P., \& Visser, K. (2020). Experimental investigations of marine diesel engine performance against dynamic back pressure at varying seastates due to underwater exhaust systems. ASME 2019 Internal Combustion Engine Division Fall Technical Conference, ICEF 2019. https://doi.org/10.1115/ICEF20197216

Sapra, H., Godjevac, M., Visser, K., Stapersma, D., \& Dijkstra, C. (2017). Experimental and simulation-based investigations of marine diesel engine performance against static back pressure. Applied Energy, 204. https://doi.org/10.1016/j.apenergy.2017.06.111

Tryggvason, G., Scardovelli, R., \& Zaleski, S. (2003). Direct numerical simulations of multiphase flow. In Multiphase Science and Technology (Vol. 15, Issues 1-4). https://doi.org/10.1615/MultScienTechn.v15.i1-4.190

Wang, M., Zhang, H., \& Gong, W. (2019). Research on airflow uniformity of marine selective catalytic reduction reverse blow system. The Journal of Engineering, 2019(23), 90839087. https://doi.org/10.1049/JOE.2018.9190

Wang, X. C., Klemeš, J. J., Dong, X., Fan, W., Xu, Z., Wang, Y., \& Varbanov, P. S. (2019). Air pollution terrain nexus: A review considering energy generation and consumption. Renewable and Sustainable Energy Reviews, 105(December 2018), 71-85. https://doi.org/10.1016/j.rser.2019.01.049

Zeng, L. (2021). 25-Meter catamaran. https://grabcad.com/library/25-meter-catamaran-2

Zhu, Y., Li, T., Xia, C., Feng, Y., \& Zhou, S. (2020). Simulation analysis on vaporizer/mixer performance of the highpressure SCR system in a marine diesel. Chemical Engineering and Processing - Process Intensification, 148. https://doi.org/10.1016/j.cep.2020.107819. 